\title{
Linking communities with conservation in developing countries: buffer zone management initiatives in Nepal
}

\author{
Prabhu Budhathoki
}

\begin{abstract}
Sustained and effective biodiversity conservation in a developing country such as Nepal is faced with the increasing pressure that the growing population exerts on the country's natural resources. Nepal has adopted a community-based approach to conservation management, including sharing of revenues from protected areas with local people living in the buffer zones around protected areas. The aim is to mitigate conflicts. This paper discusses the evolution of conservation policy for buffer zones in Nepal. The strengths and weaknesses of buffer zone policy are analysed, and the efforts to put
\end{abstract}

policy into practice are examined and discussed. The analysis of buffer zone initiatives reveals that there are inconsistencies between the vision of the programme and its policies and practices. For better integration of conservation and development objectives, empowerment and equity in benefit sharing and gender issues need to be adequately incorporated in buffer zone policy and programme implementation.

Keywords Biodiversity, buffer zone, communitybased conservation, Nepal, protected areas.

\section{Introduction}

The establishment of protected areas has been a major worldwide conservation strategy. However, despite increases in protected area coverage, those in developing countries have suffered from insufficient budgets, inadequate staff and infrastructure, and poor relations with people in surrounding lands (Barzetti, 1993). The fundamental issue of park management in developing countries is the customary rights of use of park resources by local people, and government attempts to curtail this (Borrini-Feyerabend, 1995; Ghimire \& Pimbert, 1997; Roe et al., 2000; Barrow \& Fabricius, 2002; DFID, 2002; Worha, 2002). Striking a balance between the long-term objectives of protected areas and the immediate needs of the communities living in and around them is one of the most pressing challenges facing resource managers.

In most developing countries participatory biodiversity conservation has become a strategy to address this challenge (Barber et al., 1995; Roe et al., 2000; Nepal, 2002). Approaches such as community-based wildlife management (Roe et al., 2000), community-based conservation (Ghimire \& Pimbert, 1997; Enters \& Anderson, 1999; Kellert et al., 2000; Kothari, et al., 2000) ecodevelopment (Badola, 1999; Mahanty, 2002) and buffer zone management (Nuemann, 1997; Ebregt and Greve, 2000; Martino, 2001) have been adopted to address

Prabhu Budhathoki International Centre for Protected Landscape, Aberystwyth, SY23 3AH, UK. E-mail pub@aber.ac.uk

Received 23 December 2002. Revision requested 19 June 2003. Accepted 20 January 2004 conflicts between people and protected areas and to accommodate local needs and practices in protected area management. These various approaches operate in diverse social, political and ecological contexts but common to all of them are the principles of benefit sharing and recognition of the role of local communities in conservation.

There has been debate over whether or not conservation and development can be successfully integrated (Wells \& Brandon, 1992; Wells, 1995; Hackel, 1999; Brown, 2002; Sanderson \& Redford, 2003, 2004; Brockington \& Schmidt-Soltau, 2004; Kepe et al., 2004; Roe \& Elliott, 2004) and also for and against communitybased conservation models (Nepal \& Weber, 1993; Ghimire \& Pimbert, 1997; Enters \& Anderson, 1999; Jeanrenaud , 1999; Oates, 1999; Terborgh, 1999; Roe et al., 2000; Adams \& Hulme, 2001; Wilshusen et al., 2002; Scholte, 2003). Nevertheless, the 2003 World Park Congress emphasized the need for better integration of conservation and development, and recommended that protected areas should not be viewed as islands of conservation divorced from the social and economic context within which they are located (IUCN, 2003a). The Congress' Durban Accord called for better participatory management strategies, emphasizing the need for local communities to share in protected area benefits and decision-making (IUCN, 2003b).

In comparison to other community-based conservation approaches, the systematic application of the buffer zone concept as an integrated conservation strategy is relatively recent (Ebregt \& Greve, 2000) and is still at an early stage of its evolution. However, the buffer zone 
concept has been widely used since the mid 1970s in the Man and Biosphere Programme of UNESCO (UNESCO/ $M A B, 2003)$. Although the Programme has had a profound influence on the concept of buffer zone management, there are some differences between buffer zones in the Programme and other buffer zone initiatives (Martino, 2001). There is debate about what is or should be the role of buffer zones (Nuemann, 1997; Phillips, 1998; Martino, 2001; Scholte, 2003), and successful working examples of buffer zone management as an integrated conservation strategy are relatively few, and also controversial (Wells \& Brandon, 1992; Nuemann, 1997; Brown, 2002; Scholte, 2003). The systematic application of the buffer zone concept has been limited, and Nepal and Cameroon are the only two countries where buffer zones have been legally defined (Ebregt \& Greve, 2000). The buffer zone initiative of Nepal has well defined policy frameworks to delineate buffer zones and to recycle park income for buffer zone development, and legally constituted community institutions to implement buffer zone programmes. Revenue recycling schemes attempt to redress the inequities of wildlife conservation that directly affect rural resource users (Barrow et al., 2000; Archabald \& Naughton Treves, 2001). In Nepal park authorities retain $50 \%$ of the annual park income (the remaining 50\% goes to the national treasury) and recycle this revenue in development activities, through registered community-based organizations.

This paper discusses the evolution of conservation policy for buffer zones in Nepal. The strengths and weaknesses of buffer zone policy are analysed, and the efforts to put policy into practice are examined and discussed. The analysis of buffer zone initiatives reveals that there are inconsistencies between the vision of the programme and its policies and practices. This analysis is based on both published information and on field surveys that I conducted in Royal Chitwan National Park during the first 6 months of 2003.

\section{Biodiversity conservation in Nepal}

Building a network of protected areas has been Nepal's main strategy for the long-term protection of biodiversity (Table 1). Over two decades 16 protected areas have been established that cover $c .18 \%$ of the country's surface area (DNPWC, 2003; Fig. 1). Until the early 1990s conservation strategies, particularly in the lowland Terai (a 26$30 \mathrm{~km}$ wide belt of fertile alluvial land in the south), were mainly focused on the protection of wilderness rather than on the inclusion of people. This policy, however, gave rise to direct conflicts because strict park regulations denied local people access to valuable resources. As a result many local people came to regard protected areas as a symbol of hardship and a cause of conflict (pers. obs.). To address the causes and perceptions surrounding this disaffection, arrangements were made over the past two decades for limited access for fishing and the collection of grass for thatch. Activities such as public coordination meetings have also been organized annually. However, despite these efforts, Nepal has remained a country with low conservation capacity (Cracraft, 1999). In order to address this problem various legal provisions have been enacted and major changes in conservation policy and strategy have taken place (Heinen \& Metha, 2000; HMGN/MFSC, 2002).

\section{Buffer zone management policy and strategy}

Successful community based resource management initiatives such as the community forestry programme and the Ananapurna Conservation Area Programme, as well as the changing socio-political context in Nepal following the restoration of a multi-party democratic system in 1990, encouraged the government to introduce participatory management approaches in protected areas. In 1994 the government amended the National Parks and Wildlife Conservation Act, 1973, to authorise park authorities to declare buffer zones on the peripheries of existing protected areas, and allowed 30-50\% of Park income to be recycled into local communities for natural resource management and community development. Subsequently, the Buffer Zone Management Regulations, 1996, and Buffer Zone Management Guidelines, 1999, were approved for the design of programmes compatible with national park management and to facilitate public participation in the conservation, design and management of buffer zones (HMGN/MFSC, 2002).

Nepal's buffer zones comprise a mosaic of forests, agricultural lands, settlements, cultural heritage areas, village open spaces and other types of land use, and unlike other buffer zones (Sayers, 1991) are designed as an interface between parks and people. Compared to the buffer zones of the UNESCO Man and Biospheres Programme those of Nepal are a combination of buffer and transition zones. They are designed to reduce the impact of a park on local communities, rather than serving only to form a protective layer to absorb the effects of outside intervention.

The Buffer Zone Regulations of Nepal advocate a community-based approach to the conservation of park resources through forging partnership agreements between community organizations and park authorities (HMGN, 1996). The objective is to stimulate new livelihood opportunities and the use and development of alternative natural resources such as buffer zone community forests, thus promoting community self-reliance and 


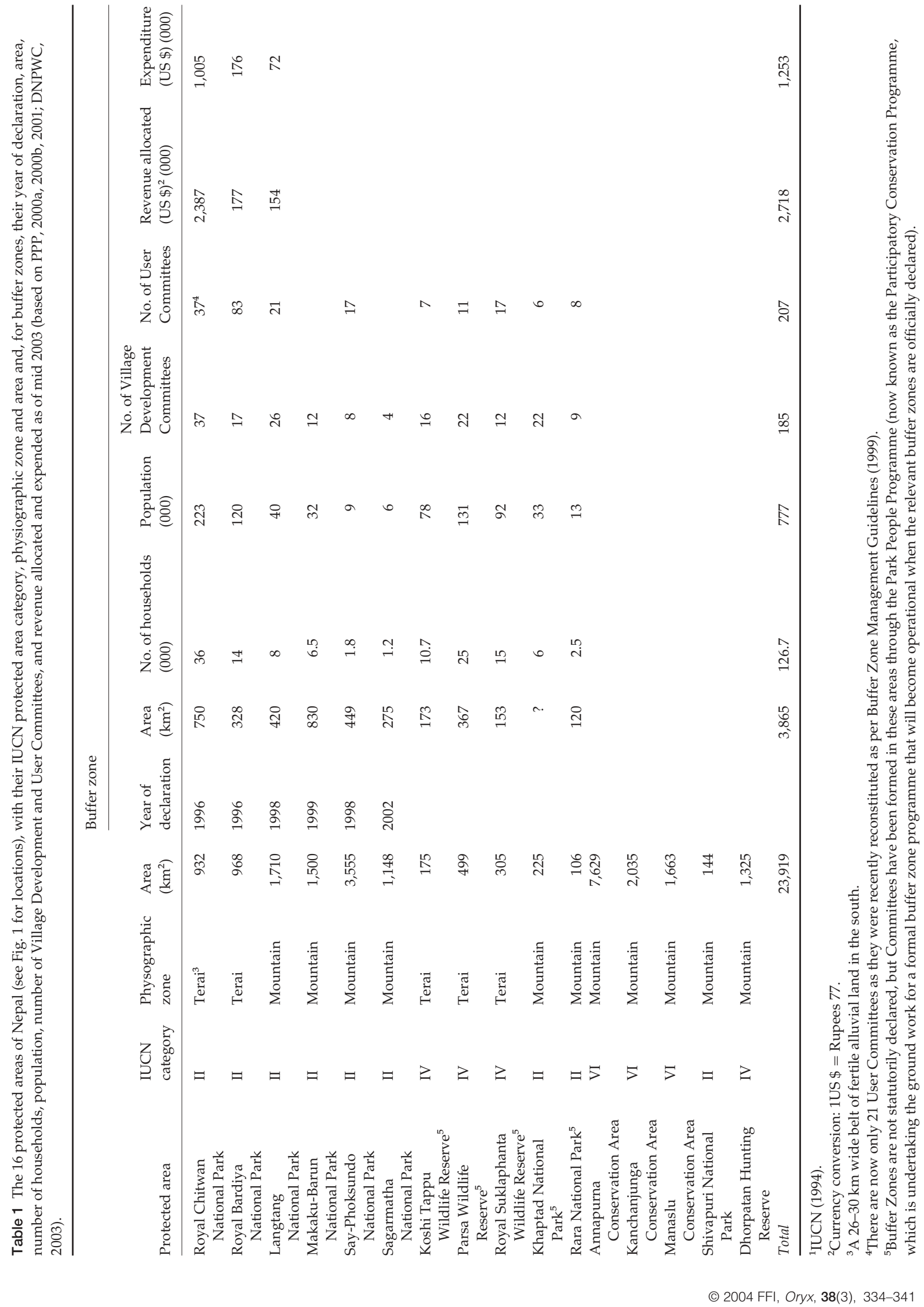




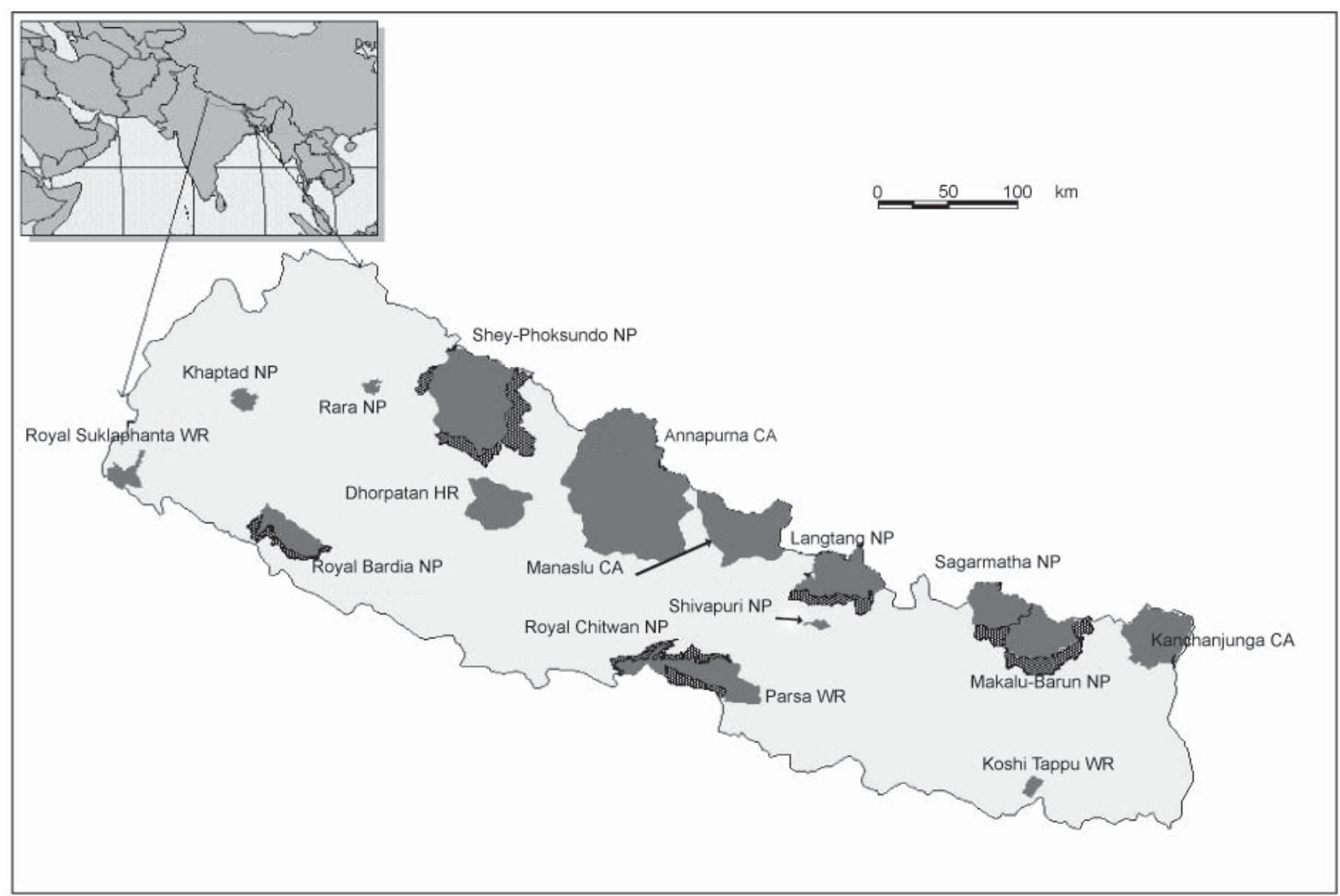

Fig. 1 Locations of the 16 protected areas of Nepal (see Table 1 for details). NP, National Park; WR, Wildlife Reserve; CA, Conservation Area; HR, Hunting Reserve.

minimizing dependence on critical biological resources. The mobilization of communities for effective buffer zone management is grounded in the principle of equitable development of human social, financial and environmental resources (Budhathoki, 2003).

\section{Translating policy into practice}

The Buffer Zone Management Regulations, 1996, and Buffer Management Guidelines, 1999, prescribe seven steps for the systematic planning and management of the buffer zone programme (Fig. 2). Areas directly affected

1. Public consultation \& delineation of buffer zone

Fig. 2 The seven steps for the systematic planning and management of the buffer zone programme, as prescribed by the Buffer Zone Management Regulations, 1996, and Buffer Management Guidelines, 1999. 
by a National Park or Reserve, because of restrictions on the use of forest products and grazing or the intensity of crop damage by wildlife, are the main criteria for delineating a buffer zone. Other factors taken into consideration are the location of the protected area, the status of any villages or settlements within a protected area, and any potential eco-tourism sites (MFSC, 1999).

In the Buffer Zone Management Regulations, 1996, a three-tier model has been adopted for the management of conservation and development activities in the buffer zones: the settlement, sector and park levels. A sector is part of a buffer zone designated for management purposes; for example, the buffer zone of Royal Chitwan National Park is divided into 37 sectors, with a User Committee in each. Communities in the buffer zone areas are mobilized through the formation of User Groups at the settlement level, and a community saving scheme (in which members deposit a certain amount of money on a weekly or fortnightly basis to create their own community fund for socio-economic development) is simultaneously established. The formation of separate male and female User Groups is encouraged (MFSC, 1999) for socio-cultural reasons and to reduce the influence of dominance hierarchies. These settlement-based organizations are then federated to form User Committees at the sector level.

At the Park level, User Committee chairpersons form a Buffer Zone Management Committee, with the Chief of the Park acting as Member Secretary. This body is entrusted to mobilize its share of the Park's revenue for development and conservation activities in the buffer zone, through the User Committees and User Groups (HMGN, 1996). Criteria for disbursing funds to the User Committee are the size and coverage of the User Groups or represented population, the impact of the User Groups on the protected area, the impact of the Park on local people, the community's geographic location with respect to the park, the community's willingness to participate in the buffer zone process, and the level of support from other agencies for the proposed project (HMGN, 1996). The Buffer Zone Management Guidelines, 1999, allows User Committees to spend 30\% of their total annual allocated funds for community development, $30 \%$ for conservation programmes, $20 \%$ for income generation and a skill development programme, 10\% for conservation education programmes, and 10\% for administrative expenses (MFSC, 1999).

\section{Status of buffer zone management in Nepal}

The buffer zone concept is now being widely applied, with 11 out of 16 protected areas (69\%) implementing the buffer zone programme (Table 1). Since 1997 > US $\$ 1.2$ million of park income has been recycled into the implementation of conservation and development activities in the buffer zone areas (DNPWC, 2003), and more than 700,000 people in 185 Village Development Committees have directly or indirectly benefited from the programme (Table 1). Moreover, the generation of community capital through voluntary saving schemes in the buffer zones reached more than US $\$ 500,000$ within 5 years of the scheme's introduction (DNPWC, 2002). If the financial value of this scheme continues to increase at current rates, then it will soon exceed the average annual disbursement of park income for community development.

\section{Discussion}

The buffer zone concept has been introduced as a key component of Nepal's conservation strategy to mitigate the impact of protected areas on local communities and thereby to reduce the adverse impacts of local people on protected areas. The strengths of the buffer zone programme in Nepal is a well-formulated policy framework and the provision of well-structured community institutions for its implementation. The initiative has been identified as one of the means to achieve people's participation in the management of protected areas (HMGN/MFSC, 2002), and has shifted the emphasis from State bureaucratic interests to local priorities. As a result there has been a high level of acceptance of the programme. Buffer Zone Management Committee representatives have expressed the view that the buffer zone programme is helping to improve their socio-economic condition, and local people consider it as the best available opportunity to access the benefits of parks for development initiatives (pers. obs.).

This involvement of local people in conservation and in the distribution of conservation benefits has improved the relationships between park authorities and local communities, and the violent confrontations of the past do not occur any more. In a field survey that I carried out in early $2003,93 \%$ of User Community presidents indicated that there had been an improvement in the relationship between park authorities and local people following the implementation of the buffer zone programme. There is increased cooperation from villagers in tackling problems such as grazing and the illegal extraction of wood from protected areas (Kothari et al., 2000).

There is now improved local awareness that buffer zones can create opportunities for the sharing of park benefits with local people, including improved access to forest resources. New Buffer Zone Management Committees have been elected in Royal Chitwan and Royal Bardia National Parks at the end of their first 5 -year term. Within the last 2 years > US \$250,000 has 
been disbursed for community development activities (DNPWC, 2003). Despite the current problems with Maoist insurgency in the country buffer zone activities have been little affected, a fact that could be considered as a testimony of community acceptance of the programme.

However, the buffer zone programme is not without problems. The programme is at different scales and stages of implementation in different protected areas (Table 1). In several areas buffer zones have yet to be officially declared, 8 years after enactment of the buffer zone policy. This delay in implementation has hampered the wider application of buffer zone initiatives and prevented the recycling of park revenues. In addition, many User Committees are not able to use their allocated budget because of inadequate support from the park. My assessment of park information early in 2003 (unpub. data) revealed that in Royal Chitwan National Park only one User Committee out of 37 had been able to utilize their fourth year of allocated funding and none were able to access the fifth year. As a result $>58 \%$ of the fund released for buffer zone management is unused (DNPWC, 2003). This issue has caused some local communities to see the buffer zone initiative as another broken government promise. The inadequate capacity of the government at both park and departmental levels has been a hindrance to effective implementation of the buffer zone programme (Budhathoki, 2003).

The issue of transparency in the use of buffer zone funds and the inadequate representation of women and indigenous people in decision-making bodies such as the Buffer Zone Management Committee is another challenge. Critics feel that the programme has not been successful in addressing the priorities of the poor, marginalized and indigenous communities living in the buffer zone (Anon, 2002; Paudel, 2002) as elites and politically influential people control the decision-making bodies and hence the financial resources. Increased access to buffer zone forest resources has been more beneficial to local elites and large-scale farmers than to marginalized indigenous communities (Timsina \& Paudel, 2003). To date, 75 and $54 \%$ of the Buffer Zone Management Committee members are, respectively, from higher castes and are active members of political parties (P. Budhathoki, unpub. data). There are not as yet any female representatives in the Buffer Zone Management Committee despite the formation of large numbers of female User Groups, and only $16 \%$ of the Buffer Zone Management Committee members are from indigenous communities.

Another potentially contentious issue is that popular high-income parks such as Royal Chitwan Park could annually recycle $c$. US $\$ 400,000$ whereas, for example, the more remote Langtang National Park receives only c. US $\$ 40,000$ per year (Table 1 ). This is a serious concern for efforts to involve households in the low-income Parks in the buffer zone programme. As more than $95 \%$ of park income comes from tourism, it will also be difficult to maintain the level of funding for high-income parks if tourism income falls. Thus adequate and sustainable financing is a significant constraint to the buffer zone programme.

It has also been contended that the present buffer zone policy and programme do not sufficiently empower local communities (Heinen \& Metha, 2000; Agrawal \& Ostrom, 2001). The key focus of the present policy has been to redistribute park income to compensate local people for restrictions on their traditional use of resources. The role of Buffer Zone Management Committees has been limited to act only as advisory bodies to park wardens in the allocation of park revenues. The dilemma for authorities is that they both need and fear people's participation (Pretty, 2002). It continues to be the case that the functional power in Nepal's protected areas, and to a large extent in buffer zone management, is concentrated in the hands of park wardens (Heinen \& Metha, 2000; Paudyal, 2001). This encourages community members to be passive beneficiaries. The buffer zone model, based as it is on a charitable and compensatory approach, may not be sufficient to ensure sustainable management of biodiversity, and there may be a need for more community empowerment in both use of resources and decision-making processes (Neumann, 1997; Brown, 1998; Colchester, 2000; Heinen \& Metha, 2000; Kellert et al., 2000; Agrawal \& Ostrom, 2001; Brechine et al., 2002).

This analysis of the strengths and weaknesses of buffer zone initiatives in Nepal indicates that there are inconsistencies between the vision of the programme and its policies and practices. There is a particular need for a study of whether the revenue-recycling scheme can adequately offset the impact of the country's parks on local livelihoods and the pressure of local communities on critical park resources. As the survival of many protected areas may depend on ensuring greater and more equitable benefits to the general public (McNeely \& Schutyser, 2003), successful implementation of the buffer zone programme in a developing county such as Nepal is relatively important. In this context, future policy revisions will need to address the issues of empowerment, equity in benefit sharing within the community, and gender issues. Nepal's experience with buffer zone programmes could provide useful lessons for similar initiatives in other developing countries.

\section{Acknowledgements}

My special thanks to Drs Shaun Russell and Liz Hughes, International Centre for Protected Landscapes, for their 
valuable suggestions and helpful improvements of this article. I also wish to thank three anonymous reviewers for their valuable comments.

\section{References}

Anonymous (2002) Kantipur, December 30, Kathmandu, Nepal. Adams, W.M. \& Hulme, D. (2001) If community conservation is the answer in Africa, what is the question? Oryx, 35, 193-200.

Agrawal, A. \& Ostrom, E. (2001) Collective action, property rights, and decentralisation in resource use in India and Nepal. Politics and Society, 29, 485-514.

Badola, R. (1999) People and protected areas in India. Unasylva, 50(4), 12-15 [http:/ / www.fao.org/docrep, accessed 22 December 2003].

Barber, C.V., Afiff, S. \& Purnomo, A. (1995) Tiger by the tail? Reorienting Biodiversity Conservation and Development in Indonesia. World Resources Institute, Washington, DC, USA.

Barro, E. \& Fabricius, C. (2002) Do rural people really benefit from protected areas - rhetoric or reality? Parks, 12, 67-79.

Barrow, E., Gichohi, H. \& Infield, M. (2000) Rhetoric or RealityA Review of Community Conservation Policy and Practice in East Africa. Evaluating Eden series no. 5, International Institute for Environment and Development, London, UK.

Barzetti, V. (1993) Park and Progress - Protected Areas and Economic Development in Latin America and the Caribbean. IUCN/Inter-American Development Bank, Gland, Switzerland.

Borrni-Feyerabend, G. (1995) Collaborative Management of Protected Areas: Tailoring the Approach to the Context. IUCN, Gland, Switzerland.

Brechin, S.R., Wilshusen, P.R., Fortwangler, C.L \& West P.C. (2002) Beyond the square wheel toward a more comprehensive understanding of biodiversity conservation as social and political process. Society and Natural Resources, 15, 41-64.

Brown, K. (1998) The political ecology of biodiversity, conservation and development in Nepal's Terai: confused meanings, means and ends. Ecological Economics, 24, 73-87.

Brown, K. (2002) Innovation for conservation and development. The Geographical Journal, 168, 6-17.

Brockington, D. \& Schmidt-Soltau, K. (2004) The social and environmental impacts of wilderness and development. Oryx, 38, 140-142.

Budhathoki, P. (2003) A category V protected landscape approach to buffer zone management. Parks, 13, 22-30.

Colchester, M. (2000) Self determination or environmental determinism for indigenous people in tropical forest conservation. Conservation Biology, 14, 1365-1367.

Cracraft, J. (1999) Regional and global patterns of biodiversity loss and conservation capacity: predicting future trends and identifying needs. In The Living Planet - Biodiversity Science and Policy in Crisis (eds J. Cracraft \& F.T. Grifo), pp. 139-172. Columbia University Press, New York, USA.

DFID (2002) Wildife and Poverty Study. Department for International Development, London, UK.

DNPWC (2002) Park People Programme - Completion Report 1994-2001. Department of National Parks and Wildlife Conservation, Kathmandu, Nepal.

DNPWC (2003) Annual Report (2002-2003). Department of National Parks and Wildlife Conservation, Kathmandu, Nepal.
Ebregt, A. \& Greve, P.D. (2000) Buffer Zones and their Management - Policy and Best Pratices for Terresterial Ecosystems in Developing Countries. International Agricultural Centre, Wageningen, The Netherlands.

Enters, T. \& Anderson, J. (1999) Rethinking and decentralisation and devolution of biodiversity conservation. Unasylva, 50(4), 6-11 [http:/ /www.fao.org/docrep, accessed 22 December 2003].

Ghimire, K.B. \& Pimbert, M.P. (1997) Social change and conservation: an overview of issues and concepts. In Social Change and Conservation - Environmental Politics and Impacts of National Parks and Protected Areas (eds K.B. Ghimire \& M.P. Pimberst), pp. 1-45. Earthscan Publication, London, UK.

Hackel, J.D. (1999) Community conservation and the future of Africa's Wildlife. Conservation Biology, 13, 726-734.

Heinen, J.T. \& Metha, J.N. (2000) Emerging issues in legal and procedural aspects of buffer zone management with case studies from Nepal. Journal of Environment and Development, 9, 54-67.

HMGN (His Majesty's Government of Nepal) (1996) Buffer Zone Management Regulation (unofficial English translation). Department of National Parks and Wildlife Conservation, Kathmandu, Nepal.

HMGN/MFSC (His Majesty's Government of Nepal/Ministry of Forests and Soil Conservation) (2002) Nepal Biodiversity Strategy. Ministry of Forests and Soil Conservation/Global Environment Facility/United Nations Development Programme, Kathmandu, Nepal.

IUCN (2003a) The Vth World Parks Congress Recommendations. Http:/ /www.iucn.org/themes/wcpa/wpc2003 [accessed 20 December 2003].

IUCN (2003b) The Durban Accord. Http:/ / www.iucn.org/ themes/wcpa/wpc2003 [accessed 20 December 2003].

Jeanrenaud, P. (1999) People oriented conservation - progress to date. In Partnership for Conservation - New Strategies for Planning and Management for Protected Areas (eds S. Stolton \& N. Dudley), pp. 126-134. Earthscan Publications, London, UK.

Kellert, S.P., Metha, J.N., Ebbin, S.A. \& Lichtenfeld, L.L. (2000) Community natural resource management: promise, rhetoric, and reality. Society and Natural Resources, 13, 705-715.

Kepe, T., Saruchera, M. \& Whande, W. (2004) Poverty alleviation and biodiversity conservation: a South African perspective. Oryx, 38, 143-145.

Kothari, A., Pathak, N. \& Vania, F. (2000) Where Communities Care-Community Based Wildlife and Ecosystem Management in South Asia. Evaluating Eden Series no. 3, Kalpavriksh and International Institute for Environment and Development, London, UK.

Mahanty, S. (2002) Conservation and development interventions as networks: the case of the India Ecodevelopment Project, Karnataka. World Development, 30, 1369-1386.

Martino, D. (2001) Buffer zones around protected areas: a brief literature review. Electronic Green Journal, Issue 15, December 2001 [http:/ / egj.lib.uidaho.edu/egj15/martino1.html, accessed 15 May 2004]

McNeely, J.A. \& Schutyser, F. (2003) Protected Areas in 2023: Scenarios for an Uncertain Future. IUCN, Gland, Switzerland.

MFSC (Ministry of Forests and Soil Conservation) (1999) Buffer Zone Management Guidelines. Ministry of Forests and Soil Conservation, Kathmandu, Nepal.

Nepal, S.K. (2002) Linking parks and people: Nepal's experience in resolving conflicts in parks and protected 
areas. International Journal of Sustainable Development and World Ecology, 9, 75-90.

Nepal, S.K. \& Weber, K.E. (1993) Struggle for Existence - Park People Conflict in the Royal Chitwan National Park. Division of Human Settlements and Development, Asian Institute of Technology, Bangkok, Thailand.

Neumann, R.P. (1997) Primitive ideas: protected area buffer zones and the politics of land in Africa. Development and Change, 28, 559-582.

Oates, J.F. (1999) Myth and Reality in the Rain Forest - How Conservation Strategies are Failing in West Africa. University of California Press, Berkeley, USA.

Paudel, N. (2002) Integrating people and nature: a perspective for environmental conservation and livelihoods in the context of Nepal. Journal of Forests and Livelihood, 2, 62-67.

Paudyal, K. (2001) Assessment of policy issues for biodiversity conservation at buffer zone of Royal Chitwan National Park. Bano Janakari, 11, 9-15.

Phillips, A. (1998) Biosphere Reserves and Protected Areas: what is the difference? In Biosphere Reserves - Myth or Reality. Proceedings of the Workshop on Biosphere Reserves. World Conservation Congress, Montreal, Canada, 1996, pp. 7-10. IUCN, Gland, Switzerland.

PPP (Park People Programme) (2000a) Consolidating Conservation through People's Participation. Park People Programme, Department of National Parks and Wildlife Conservation/United Nations Development Programme, Kathmandu, Nepal.

PPP (Park People Programme) (2000b) Royal Chitwan National Park and Buffer Zone - Resource Profile. Park People Programme, Department of National Parks and Wildlife Conservation/United Nations Development Programme, Kathmandu, Nepal.

PPP (Park People Programme) (2001) Koshi Tappu Wildlife Reserve and Proposed Buffer Zone-Resource Profile. Park People Programme, Department of National Parks and Wildlife Conservation/United Nations Development Programme, Kathmandu, Nepal.

Pretty, J. (2002) People, livelihoods and collective action in biodiversity management. In Biodiversity, Sustainability and Human Communities - Protecting Beyond the Protected (eds T. O'Riordan \& S. Stoll-Kleemann), pp. 61-86. Cambridge University Press, Cambridge, UK.

Roe, D. \& Elliott, J. (2004) Poverty reduction and biodiversity conservation: rebuilding the bridges. Oryx, 38, 137-139.

Roe, D., Mayers, J., Grieg-Gran, M., Kothari, A., Fabricius, C. \& Hughes, R. (2000) Evaluating Eden - Exploring the Myths and
Realities of Community-based Wildife Management: Series Overview. Evaluating Eden series no. 8, International Institute for Environment and Development, London, UK.

Sanderson, S. \& Redford, K. (2003) Contested relationships between biodiversity conservation and poverty alleviation. Oryx, 37, 389-390.

Sanderson, S.E. \& Redford, K. (2004) The defence of conservation is not an attack on the poor. Oryx, 38, 146-147.

Sayers, J. (1991) Buffer Zones in rainforests: facts or fantasy?

Parks, 2, 20-24.

Scholte, P. (2003) Immigration: a potential time bomb under the integration of conservation and development. Ambio, 32, 58-64.

Terborgh, J. (1999) Requiem for Nature. Island Press, Washington, DC, USA.

Timsina, N. \& Paudel, N.S. (2003) State versus community: a confusing policy discourse in Nepal's forest management. Journal of Forest and Livelihood, 2, 8-16.

UNESCO (2003) Frequently Asked Questions in Biosphere Reserves. Http://www.unesco.org/mab/nutshell.htm [accessed 24 December 2003].

Wells, M. (1995) Biodiversity Conservation and Local Peoples' Development Aspirations: New Priorities for the 1990s. Network Paper 18a, Rural Development Forestry Network, London, UK.

Wells, M. \& Brandon, K. (1992) People and Parks: Linking Protected Area Management with Local Communities. The World Bank, Washington, DC, USA.

Wilshusen, P.R., Brechin, S.R., Fortwangler, C.L. \& West, P.C. (2002) Re-inventing a square wheel: critique of a resurgent 'protection paradigm' in international biodiversity conservation. Society and Natural Resources, 15, 17-40.

Worha, S. (2002) The challenge of community-based protected area management. Parks, 12, 80-93.

\section{Biographical sketch}

Prabhu Budhathoki's research interests are communitybased resource management, conservation policy and strategy, and analysis of models of governance and their impacts on the environment, economy and community empowerment. He has been designing a research project to assess the impact of revenue sharing schemes in offsetting the pressure of local communities on critical park resources. 